\title{
The political economy of carbon capture and storage: An analysis of two demonstration projects
}

\author{
Florian Kerna, b, James Gaedec, James Meadowcroftc and Jim Watson ${ }^{b}$ \\ ${ }^{\text {a } C o r r e s p o n d i n g ~ a u t h o r: ~ J u b i l e e ~ b u i l d i n g, ~ B r i g h t o n, ~ B N 19 S L, ~ U K ; ~+441273872831 ; ~ f . k e r n @ s u s s e x . a c . u k ~}$ \\ ${ }^{\mathrm{b}}$ SPRU-Science Policy Research Unit, University of Sussex, Brighton, UK \\ ${ }^{\mathrm{c}}$ School of Public Policy, Carleton University, Ottawa, Canada
}

\begin{abstract}
Carbon Capture and Storage (CCS) technology is considered key to mitigating climate change by international institutions and governments around the world. The technology is considered advantageous because it may enable the continued utilisation of fossil fuels while curbing carbon emissions. However, development of the technology remains slow on the ground. It is generally argued that large-scale, integrated demonstration projects are needed as a next step towards commercialisation. Despite government support in several countries, few projects exist so far worldwide. This paper asks the question why it is so difficult to get demonstration projects off the ground. The argument is that it is not only project-specific factors that determine the feasibility of demonstration projects, but given the need for government support, a variety of political economy factors influence decision-making processes by policy makers and companies. The paper introduces an analytical framework developed on the basis of the political economy literature that considers six sets of factors that influence outcomes. It discusses two specific projects, Longannet in the UK and Quest in Canada, and explains why one failed and the other one is under construction. The analysis shows that although climate change is a more important policy concern in the UK compared to Canada, the specific political economy situation of fossil fuel rich provinces like Alberta has led to the Quest project going forward.
\end{abstract}

\section{Keywords}

carbon capture and storage; technology demonstration projects; political economy; UK; Canada; climate change mitigation 


\section{Introduction}

Many analysts, governments and international organizations see addressing climate change as a major challenge for science and technology policy making (Gallagher, Holdren et al. 2006; Mikler and Harrison 2011). While a number of countries have invested significant resources into developing renewable energy technologies, there is a recognition that fossil fuels will play a major role in global energy systems for years to come (IEA 2010a). Carbon capture and storage (CCS) has therefore been hailed as a key technology for climate change mitigation by the International Energy Agency (IEA), the Intergovernmental Panel on Climate Change (IPCC) and some governments including those of the US, Canada, Norway, Australia and the UK (IPCC 2005; HM Government 2010; van Alphen, Hekkert et al. 2010; IEA 2010b). The aim of CCS is to prevent the release to the atmosphere of carbon dioxide $\left(\mathrm{CO}_{2}\right)$ arising from large point sources by capturing and transporting it to an appropriate site for underground sequestration. It is argued that in this way $\mathrm{CO}_{2}$ emissions for example from a coal-fired power plant could be reduced by $80-90 \%$ (Balat, Balat et al. 2009). A key argument of proponents of CCS is that having CCS as part of the climate mitigation portfolio may significantly reduce the overall costs of meeting the mitigation target compared to portfolios not using CCS (see e.g. IPPC 2014: 41).

While there has been enthusiasm since at least 2005 when the IPCC published its special report on CCS (IPCC 2005) and while many model runs suggest that CCS could be part of the mitigation technology portfolio (Riahi, Grübler et al. 2007; Bistline and Rai 2010; Eom, Edmonds et al. in press; lyer, Hultman et al. in press), progress on the ground in terms of large scale, integrated (from capture to storage) demonstration projects has been slow. An IEA report tracking CCS progress states that "the largest challenge for CCS deployment is the integration of component technologies into large-scale demonstration projects" (IEA 2013: 5). Similarly, in 2013 the Global CCS Institute identified eight large scale integrated CCS projects around the world, but acknowledged that a number of other projects had been cancelled due to "ongoing difficulties in assembling viable business cases" (Global CCS Institute 2013: 3). By now (2015), the Global CCS Institute counts 14 large-scale CCS projects in operation, most of which work on natural gas processing. The first large-scale, integrated CCS project on a commercial coal-fired power plant has opened at Boundary Dam in the Canadian province of Saskatchewan in October 2014, but several US projects have been delayed. Moreover, by mid 2015 the final investment decision had not been taken to build a single large-scale, integrated demonstration project within the European Union (although there are several prominent projects such as the Rotterdam Opslag en Afvang Demonstratie project (Road), which has yet to receive a final investment decision by its 
proponents), although funds to support such activities had been set aside since 2012. In July 2014 the EU commission awarded $€ 300 \mathrm{~m}$ of funding to a proposed White Rose project in the UK where front-end engineering and design work is currently taking place, but no final investment decision has yet been taken.

What is a CCS 'demonstration' project and what function does demonstration serve? Technological demonstration can be understood as a process of social learning, involving not only the working out of scientific or technological uncertainties in the operation of the technology but also the generation of accepted facts about the technology, the promotion or 'selling' of the technology by interested parties to secure public or government support (Shapin 1984; Rosental 2005). CCS demonstration projects are intended not only to show that CCS physically works, but also that it can work in the context of existing social, political and economic problems, relations and interests. So while CCS is seen as an important option for reducing carbon emissions by some, progress on actually 'demonstrating' this has been slow (de Coninck, Stephens et al. 2009). This article examines why it has been so difficult to get large-scale, integrated CCS demonstration projects off the ground. It develops a political economy perspective on the complex array of factors that have influenced the enthusiasm to develop demonstration projects, and which have pushed some projects to proceed and others to stall. A political economy perspective combines the analysis of political and economic factors which - in the case of CCS - closely interact, as without policy support there is no business case to invest in CCS. This framework will be explained in more detail in section 2 .

The paper is structured as follows: In the next section, we review the relevant CCS literature, outline a political economy perspective on the challenges of technological demonstration and argue why such an approach is helpful in understanding the difficulties of CCS. The remainder of this article presents two case studies, the Scottish Power Longannet project in the UK (section 3) and the Shell Quest project in Alberta, Canada (section 4). Section 5 presents the analysis. Section 6 discusses the conclusions that can be drawn from the analysis.

\section{A political economy perspective on challenges of CCS demonstration}

Approaches to understanding technological development and deployment tend to gravitate around two poles. At the micro-level, a focus on project-level organisational and technological characteristics predominates, and the question of whether or not to proceed with a proposed technological solution to 
a given problem often comes down to the costs and risks of that approach in comparison to alternatives (e.g. see Bergerson and Lave 2007; Abadie and Chamorro 2008; Szolgayova, Fuss et al. 2008). At the macro-level, on the other hand, broader structural trends predominate and the analysis focuses on large scale, socio-technological systems associated with key areas of social life such as transportation, electricity or agro-food production and how they change (Geels 2004; Nykvist and Whitmarsh 2008; Foxon, Hammond et al. 2010; Verbong and Loorbach 2012). A political economy perspective tries to situate itself somewhere between these two poles, examining the interplay of a range of economic, political and institutional factors in technology-related decision-making processes involving government and private sector actors.

The entry of CCS onto the global climate change agenda has led to an emerging social science literature on CCS. The majority of this work clusters around two areas: (a) the economics of CCS and the role CCS should play within different mitigation scenarios (Rubin, Chen et al. 2007; Otto and Reilly 2008; van der Zwaan and Gerlagh 2009); and (b) the public acceptability of CCS (van Alphen, Voorst et al. 2007; de Coninck, Flach et al. 2009; Shackley, Reiner et al. 2009). While there has been recognition of the importance of political factors contributing to the uncertainties surrounding CCS (Markusson, Kern et al. 2012; Watson, Kern et al. 2014), consideration of this dimension has largely focused on their impact on the economics of the technology - highlighting, for instance, the importance of adequate policy and regulatory frameworks to address the 'financial gap' and to resolve questions about long-term liability.

The existing literature on CCS is therefore largely 'instrumental' in character, examining the various policy approaches that might stimulate CCS development and trying to find the most effective solution (Groenenberg and de Coninck 2008; Scrase and Watson 2009; von Stechow, Watson et al. 2011; Backstrand, Meadowcroft and Oppenheimer 2011). At this level of analysis the answer to our research question (understanding the difficulty of getting demonstration projects off the ground) is to point to the absence of policy and regulatory frameworks adequate to assuage industry uncertainty and resolve the 'financial gap'. Add to this a policy paradigm (at least in most OECD countries) that emphasizes markets and 'technological-neutrality' of policy interventions in the energy sector (Kern, Kuzemko et al. 2014), and one arrives at the received wisdom concerning the barriers to successful demonstration: CCS cannot currently be justified as an emissions-reducing technology at the project level in the absence of substantial public incentives, which could be supplied through economy-wide carbon pricing (with a sufficiently high carbon price) and/or direct financial subsidies. 
Yet there remain unaddressed issues that are clearly relevant to why such demonstration projects are hard to get off the ground. While the financial gap and lack of carbon pricing are indeed important barriers, the factors that play into governments' decisions to do (or not to do) something about these barriers are rarely if ever considered. Nor does this speak to the role that varying access to government by energy sector interests might play in shaping policy outputs. In short, what is missing in the existing literature on CCS is a more critical analysis of the complex interplay of factors that shape policy at the intermediate state/market level. It is here that a political economy framework for understanding technological development can be most fruitful. The focus at this intermediate level - between sitespecific projects and larger macro-trends - is not on what policies are most effective or efficient in deploying CCS, or on defining the place of CCS in a 'truly sustainable' energy system. Instead, it is on the factors that influence social, technological and policy choice and design over a medium-term timeframe (5 to 10 years).

Political economy is defined by its interest in the relationship between the state and the market (Gamble, Payne et al. 1996) and how the interaction between the two contributes to outcomes in either sphere. The relationship of primary concern in assessing CCS demonstration project development is that between public policy makers and private enterprises. In this context, it is worth emphasising that the realization of a large-scale CCS demonstration project requires a substantial commitment from both government and the industrial actors that will build and operate the facilities. Precisely because it involves demonstration of technological systems that are not fully commercialized, we are a long way from 'business as usual' for either party. CCS projects are expensive, involving large upfront investment, and continuing costs for $\mathrm{CO}_{2}$ capture, transport and disposal over the life of the plant. They present substantial risks to all participants including, for example, construction over-runs, technological problems (integrating CCS reliably with the normal plant operations, or unforeseen difficulties at the storage site), and reputational risks to firms, regulators and politicians should things go wrong (Markusson, Kern et al. 2012). These projects are complex, not just from an engineering perspective, but also in terms of financing and regulatory arrangements, and interactions with multiple partners and publics. Although governments could in principle build such projects themselves, in practice in OECD countries their role is primarily focused on funding and regulation, with construction and operation left to industrial actors (although in some cases these may ultimately be state-owned firms). The decision to go ahead and build such a project involves complex negotiations, and the approval of both government 
and the companies concerned. The lumpy character of the investment, and the risks and complexities of these projects, suggest that they are likely to be difficult to get off the ground.

Moreover, the political economy inspired literature has pointed to an important contrast between CCS and other low carbon technological options (such a wind or solar). Since CCS is essentially a pollution control technology that is to be married with existing fossil energy systems, many of its 'natural' proponents (producers of fossil fuels, operators of large scale combustion facilities) face split incentives (Meadowcroft and Langhelle 2009). In a climate constrained world these parties would gain from the availability of low cost CCS, because they could continue to exploit their fossil energy reserves. Yet in the short term CCS represents a headache: it is very expensive, untried at scale, and imposes additional business risks. So firms may be encouraged: (a) to delay investment in proving CCS at scale (since to the extent that it is proven -- say for coal-fired power generation -- the demand from the public and regulators to deploy it will immediately rise), and/or (b) to resist policy measures (such as carbon pricing or emissions regulations) that would drive CCS innovation, but which represent a major cost penalty today. In contrast, proponents of non-fossil energy systems (e.g. based on renewable energy technologies) have a direct incentive not only to accelerate the development of these technologies (to improve their characteristics and reduce price), but also to lend political support to stronger climate policy which would only make their products more cost-competitive. The effect described here seems to be most pronounced with coal producers and coal-fired electricity generators where 'clean coal' often appears as a future ideal as long as it does not need to be paid for today. The situation with the oil and gas industry is more nuanced. There is greater familiarity with the technologies involved in CCS (for example, $\mathrm{CO}_{2}$ separation is often necessary for gas production and $\mathrm{CO} 2$ injection has long been used for enhanced oil recovery, EOR). Moreover some firms see business opportunities related to capture, transport or storage.

The character of CCS as an 'end of pipe' technology also has potential political salience. It is relatively easy for opponents to characterise CCS as a 'bury and forget' technology that fails to represent a decisive break with fossil energy systems that are causing so much climate (and other environmental) damage (Stephens 2014). So the strongest proponents of vigorous climate policy may have ambivalent (or even hostile) attitude to CCS. What some present at CCS's greatest virtue (its continuity with dominant energy systems) appears also as its greatest weakness. 
Accordingly, this paper builds on the existing literature on the political economy of CCS (Meadowcroft and Langhelle 2009; Torvanger and Meadowcroft 2011) and the political economy literature more generally (Hayward 1998; Chang 2002; Hay 2004; Mikler and Harrison 2011; Meadowcroft 2005) to develop a framework for analysing the political economy of CCS demonstration projects. This framework differs from macro perspectives on innovation and technology development by structuring the search for specific political and economic factors that influence comingled public/private decisions on technology demonstration. Thus, for example, it offers an alternative (and in this context a more focused and politically sensitive) framework to the 'multi-level perspective' with its accent on nicheregime interactions in the context of an evolving 'landscape' (Geels 2002). The analytical framework is presented in a simplified form in Figure 1.

Figure 1: Political economy factors influencing realization of specific CCS demonstration projects

\section{Government policy objectives, frameworks and measures}

1. Project
characteri
stics
Technical

\section{Political-} institutional factors

Policy legacies and paradigms
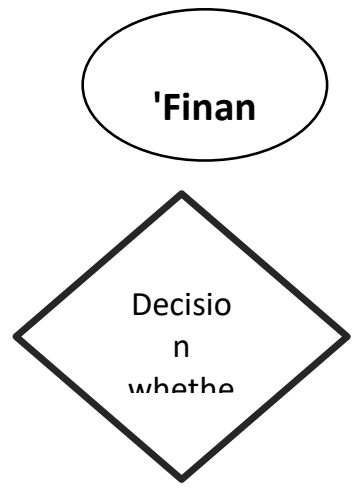

\section{Economic} factors

General economic
5. Public and political opposition or receptivity to<smiles>[CH][TlH]</smiles>

6. International dimensions

Markets 
The figure presents six broad sets of factors which political economy literatures suggest might influence decisions about the implementation of specific CCS demonstration projects. It is important to point out that these factors are not considered as static; rather they interact dynamically during the negotiation processes described in section 3 and 4 . The following text briefly explains the factors and from which sources they were derived. A summary is provided in Table 1.

As existing literature on CCS demonstration projects illustrates, outcomes are clearly influenced by the nature of the project, including its technical features, the strategic goals and resources of the organizations that would finance, build and operate the facility, the potential for EOR revenues, and so on (factor 1) (IEA 2013, Global CCS Institute 2013). Existing government priorities and policy regimes are a second element, especially the orientation and stringency of climate policy and the nature of more specific CCS support measures, but also more general energy policy concerns (including costs and security of supply) (factor 2). The importance of government priorities and policy regimes for development, demonstration and deployment of climate mitigation technologies has been emphasized by the political economy literature on 'green industrial policy' (Muzzucato 2014; Rodrik 2004, 2014; Schwarzer 2013). istorically contingent political-institutional structures (factor 3) provide an important context within which policy and economic decision making processes take place (Chang 2002; Eberlein and Doern 2009; Kern 2011). This includes policy legacies as well as the specific institutional set up (Kuzemko 2013). More broadly it includes legal/constitutional arrangements such as federal division of powers the executive, legislature, court linkages and the electoral system. Economic factors represent another significant dimension, including issues relating to resource endowments and the scale of fossil fuel extraction industries, economic development trajectories, key economic interests and actors (Eberlein and Doern 2009; Torvanger and Meadowcroft 2011) (factor 4). The presence of public and political opposition to, or support for, CCS - either generally or in the specific community where a project is proposed can also play a major role (Brunsting, Best-Waldhober et al. 2011) (factor 5). Finally, international dimensions, relating for example to respect for international agreements, or the potential creation or loss of markets, can play a role (factor 6$)$, for the general significance of such 
international/national linkages is now well established in the political economy literature (Frieden and Martin 2003; Oatley 2015).

Each of these factors can influence perception of the 'financial gap' that confronts project proponents, but can also influence the perspectives of governments and proponents directly. It is important to note that these factors are not entirely independent, for at a deeper level economic factors may influence the character of the policy regime, political-institutional factors may influence the behaviour of economic actors, and so on. But these classes of factors are nevertheless helpful in understanding the circumstances that are more or less favourable to getting demonstration projects off the ground. We argue that the factors in Figure 1 all point to potentially important elements influencing decisionmaking, but that the relative significance of these factors will vary in each case of CCS demonstration and cannot be determined a priori, and therefore must be established by empirical investigation of specific projects. The two case studies are used to assess this framework and to discover how different elements interact with one another in decision-making processes.

Table 1: Summary of political economy factors

\begin{tabular}{|c|c|c|}
\hline Factor & Definition of factor & $\begin{array}{l}\text { Examples of potential impacts on CCS } \\
\text { demonstration project go/no-go } \\
\text { decisions }\end{array}$ \\
\hline $\begin{array}{l}\text { 1. Project } \\
\text { characteristics }\end{array}$ & $\begin{array}{l}\text { Core features of the proposed demonstration facility, including } \\
\text { technical characteristics (CO2 source, capture technology, } \\
\text { transport options, storage formation, location, scale); project } \\
\text { partners (participating firms, public sector partners, proprietary } \\
\text { technologies); project financing (private funding, public } \\
\text { funding); Enhanced oil recovery options. }\end{array}$ & $\begin{array}{l}\text { More technically demanding projects, with multiple } \\
\text { private partners, and without an added revenue stream } \\
\text { from EOR are less likely to go ahead. }\end{array}$ \\
\hline $\begin{array}{l}\text { 2. Government } \\
\text { policy } \\
\text { objectives, } \\
\text { frameworks } \\
\text { and measures }\end{array}$ & $\begin{array}{l}\text { The specific government objectives, frameworks and measures } \\
\text { that regulate the energy/climate policy field within which CCS is } \\
\text { articulated as a policy solution. This includes the general } \\
\text { orientation of energy policy (preoccupations with energy } \\
\text { security, costs, revenues, regional development, etc); the } \\
\text { overall character of climate policy (stringency, targets, favored } \\
\text { policy instruments, carbon pricing mechanism and level, etc); } \\
\text { and the CCS-specific policy initiatives (regulatory frameworks, } \\
\text { financing mechanisms, R\&D support, liability regime, etc). }\end{array}$ & $\begin{array}{l}\text { Strong climate policy objectives, carbon pricing } \\
\text { mechanism with a substantial incentive for emissions } \\
\text { abatement, and regulatory clarity and simplicity, favor } \\
\text { CCS demonstration projects. }\end{array}$ \\
\hline $\begin{array}{l}\text { 3. Economic } \\
\text { circumstances }\end{array}$ & $\begin{array}{l}\text { Economic circumstances, beyond the project specific financing } \\
\text { considered in factor } 1 \text { above. These include the general macro } \\
\text { economic climate, established resource endowments, fossil fuel } \\
\text { reserves, scale of fossil extraction in the economy, public } \\
\text { finance and export earnings. }\end{array}$ & $\begin{array}{l}\text { Difficult economic circumstances (recession, low } \\
\text { resource prices) make CCS demonstration projects less } \\
\text { likely to go ahead. Substantial remaining fossil fuel } \\
\text { reserves, and fossil energy extraction assuming a } \\
\text { prominent place in economic activity, government } \\
\text { revenues and exports favour CCS demonstration } \\
\text { projects. }\end{array}$ \\
\hline
\end{tabular}




\begin{tabular}{|c|c|c|}
\hline $\begin{array}{l}\text { 4. Political- } \\
\text { institutional } \\
\text { structures }\end{array}$ & $\begin{array}{l}\text { Established characteristics of the political and policy system } \\
\text { which structure interactions of political and societal actors } \\
\text { dealing with energy and climate related issues, including: policy } \\
\text { legacies and paradigms, political culture, and constitutional } \\
\text { allocations of power across branches of government and } \\
\text { geographic space (federalism). These political institutional } \\
\text { structures influence the way political power is articulated and } \\
\text { exercised, establishing avenues for influence and points of veto. }\end{array}$ & $\begin{array}{l}\text { Established regulatory structures and political norms } \\
\text { may favour or discourage state support for large scale } \\
\text { demonstration plants. Political system variables may cut } \\
\text { either way, facilitating the action of proponents or veto } \\
\text { players in different contexts. }\end{array}$ \\
\hline $\begin{array}{l}\text { 5. Public and } \\
\text { political } \\
\text { opposition or } \\
\text { receptivity to } \\
\text { CCS }\end{array}$ & $\begin{array}{l}\text { Technology specific perspectives on CCS articulated by } \\
\text { politicians, civil society organizations, the media and the public. } \\
\text { These can be supportive, critical or broadly neutral. They are } \\
\text { manifest at two distinct but interrelated levels: (a) in general } \\
\text { political/policy argument (Is CCS a good idea? Should } \\
\text { governments be funding it? Is it safe? Does it perpetuate fossil } \\
\text { fuel dependence?); and (b) in local communities where CCS } \\
\text { demonstration project are to be cited. }\end{array}$ & $\begin{array}{l}\text { Strong political and/or public opposition either } \\
\text { generally or at the local level makes CCS demonstration } \\
\text { project less likely to go ahead. }\end{array}$ \\
\hline $\begin{array}{l}\text { 6. International } \\
\text { dimensions }\end{array}$ & $\begin{array}{l}\text { International linkages which impact decision-making by public } \\
\text { and private parties, including international agreements (around } \\
\text { climate change), threats and opportunities for markets (for } \\
\text { fossil energy, CCS related technologies). }\end{array}$ & $\begin{array}{l}\text { Stronger adhesion to international climate agreements } \\
\text { should make public and private actors more enthusiastic } \\
\text { about CCS demonstration. Threats to market access } \\
\text { should increase appetite for demonstration projects. }\end{array}$ \\
\hline
\end{tabular}

The analysis in the following sections looks at the interaction between states and markets in two cases of large-scale integrated CCS demonstration projects: a project which failed to secure final investment decision in the UK (Longannet) and a successful project in the Canadian province of Alberta (Shell Quest). Using a process tracing methodology (George and Bennett 2005), we focus on the political and economic dynamics that have contributed to the contrasting results and which illustrate the difficulties confronting CCS demonstration projects. The analysis draws on both secondary sources (including IEA reports, academic literature, etc) and primary energy and economic data from variety of sources, project documentation, policy documents etc.

\section{CCS in the UK and ScottishPower's Longannet demonstration project}

Energy and climate change policy in the UK have become closely aligned over the last decade. At least since the Energy White Paper in 2003, long term decarbonisation targets to combat climate change have played an important part in UK energy policy (DTI 2003; Scrase and MacKerron 2009) (factor 2). A dedicated Department for Energy and Climate Change was established in 2008, bringing together responsibilities for energy policy and climate change (factor 3 ). A legally binding $80 \%$ carbon reduction target by 2050 was enshrined in the 2009 Climate Change Act. The electricity sector is supposed to play a particularly important role in meeting climate change targets and the government is aiming to significantly decarbonise the sector by 2030. CCS, alongside nuclear power and offshore wind, has been 
foregrounded as a central plank of UK energy and climate change policy (HM Government 2009) (factor 2). This position reflects the UK Government's view that CCS has the potential to make a major contribution to meeting the UK's $\mathrm{CO}_{2}$ reduction targets:

'By 2020 well over half of the UK's electricity generation will still be fuelled by coal and gas. That is why CCS is such a crucial element of this Government's energy and climate change agenda. It is the only technology that can significantly reduce $\mathrm{CO}_{2}$ emissions from fossil fuel power stations - by as much as $90 \%$. IEA analysis has shown that without CCS, halving global emissions by 2050 will be 70 per cent more expensive' (DECC, 2011c).

Energy security is also a key concern of policy makers (DTI 2007). CCS is seen as one of the technological options to help deliver on both these policy goals as it allows the continued use of fossil fuels to increase or maintain energy security, but in a way which is consistent with stringent carbon reduction targets (Scrase and Watson 2009) (factor 2). Internationally, the UK wants to be seen as a leader in climate change mitigation policy and to accelerate commercialisation of the technology so it will be available globally, for example in countries such as China and India (factor 6). The UK had a Kyoto target of reducing emissions by $12.5 \%$ compared to 1990 by $2008-2012$ and managed to achieve an emission reduction of $22.5 \%$ (factor 2). The UK government is actively encouraging countries to pledge emission reduction targets for 2020 under the UN framework, and supports proposals for a $30 \%$ reduction target for EU emissions by 2020 compared to 1990 levels (factor 6).

However, given the early stage of development of CCS, a number of large-scale demonstration projects (the UK government hopes to support four) and the subsequent commercialisation of the technology (assisted through policy support such as 'contracts for difference ${ }^{1}$ ) are seen as key next steps (factor 2). The Department of Energy and Climate Change's aspiration was that the demonstration projects would help ensure CCS was ready for commercial deployment by 2020, and in particular, that the further three projects would assist in the 'transition to commercial viability' after the 'initial demonstration at commercial scale' (DECC, 2010c: 17).

In 2007, the UK government therefore launched a competition to build the UK's first large integrated demonstration plant. The aim was to 'make the UK a world leader in this globally important technology' (DECC, 2009; DTI, 2007: 15). Capital support of $£ 1$ bn was offered. The competition was restricted to post-combustion capture on a coal-fired power station (factor 2). Nevertheless, nine competing projects 
were proposed by the private sector. After assessing the technical competence of the bidders at a prequalification stage, the number of competing projects was reduced to four. By November 2009 just two bidders remained, as both BP and the Peel Consortium withdrew from the competition (NAO, 2012). But on the same day this development was made public, E.ON also withdrew its bid on the grounds that economic conditions were not right (factor 3). This left Scottish Power's Longannet project as the only remaining participant in the competition.

Their project was based on a collaboration between ScottishPower (one of the UK's 'big six' utilities), National Grid (the company operating the gas transmission grid in the UK) and Shell. The Longannet CCS project was planned on a $2.4 \mathrm{GW}$ coal-fired power plant in Scotland which opened in 1969. Within this consortium, ScottishPower was responsible for the post combustion carbon capture and compression at Longannet power station. The ambition was to capture and store 20 million tonnes of CO2 over a 10-15 year period by retrofitting an amine-based carbon capture unit onto parts of the power plant (300MW capacity). Aker Clean Carbon was to be the carbon capture technology provider. National Grid was responsible for onshore transport and compression at St Fergus. Transport of the carbon would take place largely through existing pipelines operated by National Grid, but about $100 \mathrm{~km}$ of new pipelines were required. Shell was responsible for offshore transport and storage. Carbon storage was to take place in a depleted offshore gas field. The project was supposed to start operating in 2014 (Markusson, Ishii et al. 2011; ENDS Report 445) (factor 1).

However, in October 2011 the Scottish power consortium also pulled out of the competition. The developers concluded that their plant would cost $f 1.2-£ 1$.5bn whereas only $f 1 b n$ of public funding was available (Scottish Power CCS Consortium, 2011a). DECC cited increased costs and the inability to reach a commercial agreement as the reasons for the collapse of the project. In a critical report that sought to draw lessons for the government, the National Audit Office pointed to a number of contributory factors (NAO, 2012). These included poor commercial awareness within government, a lack of government capacity to procure such large, complex projects, a lack of flexibility with respect to project specifications and the lack of a business case for the competition. Newspaper articles citing sources close to the negotiations argued that a crucial point of disagreement between the consortium and the government had been a tax exemption of the plant from the proposed carbon floor price (Vass, 2013). 
After the collapse of the negotiations DECC moved quickly to confirm that the $f 1 b n$ set aside for the first demonstration would be 'available for a new process' (DECC, 2011b). Further confirmation of the UK Government's aspirations for CCS were contained in the December 2011 Carbon Plan (DECC, 2011d). The Plan foresees up to 10GW of CCS plants in the UK by 2030. The Plan also makes it clear that the government's enthusiasm is dependent on how CCS technologies fare in comparison with other low carbon options. It states that the overall objective is to 'run a low carbon technology race between CCS, renewables and nuclear power' (DECC, 2011d: 72). Nevertheless, the then Energy Minister Charles Hendry MP stated in a subsequent speech that he wanted to 'emphasise the UK Government's firm commitment to Carbon Capture and Storage (CCS) and our determination to see the technology ready to be commercially deployed in the 2020s' (Hendry, 2012).

In summary, despite political commitment to demonstrate CCS in the UK since at least 2005, and despite the availability of $£ 1$ billion in public subsidies to support demonstration, it has proven to be impossible so far to procure a large scale, integrated CCS demonstration project. However, government efforts to procure such a project continue. In March 2013 the competition entered the next phase with DECC announcing two preferred bidders (the Peterhead Project, and the White Rose Project) (DECC 2013) and in early 2014 DECC announced $f 100 \mathrm{~m}$ funding for both consortia to undertake front end engineering and design studies which are now underway. The White Rose project would also receive EU funding once a final investment decision is taken and match funding from DECC is obtained.

\section{CCS in Canada and Shell's Quest project}

Although Canada was an early advocate of international action on climate change and - after much internal political wrangling - ratified the Kyoto Protocol in 2002, the country has so far failed to adopt carbon pricing and comprehensive greenhouse gas (GHG) controls at the national level (factor 2). A carbon intensive economic development trajectory, continuing population and economic growth, and a rapidly expanding oil export sector (factor 3 ) were always going to make attainment of an overambitious Kyoto target difficult. Add to this a decentralized constitutional structure which places natural resource ownership in provincial (rather than federal) hands, the bitter legacy of the National Energy Policy enacted by the federal government in response to 1970 s oil shocks which was perceived in Western Canada as a federal 'resource grab' (factor 4), and the repudiation of the Kyoto Protocol by the Unites States (Canada's main trading partner) (factor 6), and some of the reasons that prompted successive Liberal governments continuously to defer domestic action on climate change become clear 
(Macdonald 2009). The current Conservative government, which has vocally opposed national carbon pricing and consistently minimized climate risks, announced in 2009 that henceforth Canada's GHG abatement policies would be explicitly aligned with those of its neighbor to the south, and signalled toward the end of 2011 its intention to withdrawal from the Kyoto Protocol, a decision which took legal effect on 11 December 2012 (factor 2).

Previous work has shown that some of the developed countries that had the most difficulty with the Kyoto protocol (Australia, Canada, and the United States) were among the most enthusiastic supporters of CCS (Meadowcroft and Langhelle, 2009). In these jurisdictions, substantial funding for technological innovation was to some extent presented as an alternative to the early introduction of carbon pricing. There is no doubt that the Canadian government sees CCS as of potential strategic significance to the country's long term economic prosperity, and support for CCS research and demonstration has been a centrepiece of federal climate initiatives (factor 2). Yet in the absence of national leadership on carbon pricing, much climate change policy is also being undertaken at the provincial level. CCS figures in the climate change action and energy planning of several provinces, but it is mainly in the prairie provinces of Alberta and Saskatchewan that CCS is being actively pursued. Shell's Quest project is being developed outside of Edmonton, Alberta.

Alberta's approach to climate change was initially based on voluntary measures, but concern that the federal government might act unilaterally in this area led the province to propose its own (truncated) carbon pricing regime in 2007. The Greenhouse Gas Reduction Program passed in that year requires facilities that emit more than 100,000 tonnes of GHGs a year to reduce their carbon intensity by $12 \%$ (from a baseline date of July 1, 2007). Businesses that fail to meet their intensity targets can (a) acquire emissions credits from another covered facility, (b) purchase offsets from an Alberta-based entity or generate offsets internally though investment in specified technologies, or (c) pay a levy to a Climate Change and Emissions Management Fund (CCEMF) (Leach 2012). The price companies must pay for a tonne of emissions if they select the final option was set at $\$ 15$ and has not yet been altered. ${ }^{2}$ Since its inauguration, the program has contributed $\$ 257$ million to the fund, nearly half of which has been committed to a variety of projects, some of which are CCS-related (Environment Canada 2012). Alberta's current climate change action plan, entitled Responsibility/Leadership/Action, was released in 2008 and elaborates a three-pronged strategy centered on conservation/efficiency, greening energy production, and implementing CCS. CCS accounts for the lion's share of emissions reductions under this plan - 
approximately $70 \%$ of the 2050 target of 200 megatonnes below a business-as-usual projection for that year (Alberta 2008) (factor 2).

In April 2008 the Alberta government also passed the Carbon Capture and Storage Funding Act which set aside $\$ 2 \mathrm{bn}$ to help fund the development of CCS in the province. The government established a Carbon Capture and Storage Development Council to advise the province on how to proceed with creating an environment conducive to the technology. The report of the council provided a long list of policy, regulatory and technological recommendations, most of which are summed up by what the Council termed the 'key ingredient': sustained will. In practice, this meant significant government funding (over and above the announced $\$ 2 \mathrm{bn}$ ) and a concerted effort to put in place a regulatory framework to provide clarity and certainty to industry and assurances on safety and environmental impact to the public (Alberta Carbon Capture and Storage Development Council 2009). In 2010 the province passed the Carbon Capture and Storage Amendment Act, a key piece of legislation that amended several other acts in order to address concerns about long-term liability and storage space ownership (factor 2).

Quest is one of several fully-integrated CCS projects in Canada. Other projects include Boundary Dam in Saskatchewan (a coal-fired electricity plant), the Alberta Carbon Trunk Line or ACTL (gas processing and fertilizer manufacturing), and the Fort Nelson CCS project in northern British Columbia (gas processing). The plan for Quest is to capture emissions from three hydrogen manufacturing units attached to Shell's Scotford Upgrading plant in Fort Saskatchewan, Alberta, using Shell's activated amine capture technology called "Shell ADIP-X". The hydrogen is used to upgrade bitumen produced from the Athabasca Oilsands Project (AOSP, a collaborative initiative between Shell Canada Ltd., Chevron Canada Ltd., and Marathon Oil Canada Corporation) (factor 1).

Quest will contribute to Shell's compliance with Alberta's emissions regulations as well being part of a larger corporate strategy to lower the carbon intensity of their business. The project has the capacity to capture up to 1.2 million tonnes of $\mathrm{CO}_{2}$ a year until 2025, reducing the emissions resulting from the hydrogen production plant used to process the bitumen by $80 \%$. However, the energy penalty associated with the process itself will result in additional emissions of between 162 and $238 \mathrm{kt} \mathrm{CO}_{2} \mathrm{e} / \mathrm{a}$. Expansions to the upgrader and the inclusion of a bitumen blending plant will dramatically increase the emissions of the Scotford facility as well. In all, after the additional projects, Quest will only reduce GHG emissions from the upgrader on the order of about $15-16 \%$ (from $5,582 \mathrm{kt} \mathrm{CO2e/a} \mathrm{to} 4,700 \mathrm{kt} \mathrm{CO2e/a).}$ 
The initial cost estimate was between $\$ 900 \mathrm{~m}$ and $\$ 1.2 \mathrm{bn}$ in capital costs and between $\$ 34 \mathrm{~m}$ and $\$ 42 \mathrm{~m}$ in annual operating costs (factor 1 ).

Quest's timeline mirrors that of CCS policy developments in Alberta. Shell began working on preliminary designs for Quest in early 2008 and initially expected to make a final investment decision in the first quarter of 2012. The company undertook extensive community consultation throughout 2008 and 2009, before submitting three project applications and an environmental impact assessment to the Alberta Energy Resources Conservation Board (ECRB) in 2010. These were approved in July 2012, with only a few conditions mainly pertaining to additional reporting. In 2011, the provincial government announced it would contribute $\$ 745 \mathrm{~m}$ over 15 years from the dedicated CCS fund to QUEST. In the wake of the highprofile cancellation of another proposed CCS project in the province (owing to the financial cost of CCS in the absence of significant carbon pricing and/or a willing partner to purchase emissions for enhanced oil recovery) the province announced it would offer a double-crediting for emissions reductions that took place by way of CCS. ${ }^{3}$ Shell also sought and received $\$ 120 \mathrm{~m}$ of funding from the federal government's Clean Energy Fund. The final investment decision to proceed with the project was taken on the $5^{\text {th }}$ of September 2012. In August 2014, Shell reported that construction of the capture facility was 70 per cent complete, with the facility start up scheduled for September 2015.

\section{Analysis: The Political Economy of CCS Demonstration in Canada and the UK}

In this section, we reflect on similarities and differences between the two CCS demonstration project decision-making processes along the key political economy factors (as outlined in Figure 1 and Table 1). Our aim here is to test the suggested conceptual framework and to illuminate the complex interplay of political and economic factors that influence both industry and government decision-making regarding CCS, and which are argued to make the demonstration of the technology a more or less challenging affair at different times and/or places. Figures 2 and 3 highlight key insights from our analysis which will be discussed in more detail below.

In terms of project characteristics (factor 1), Longannet and Quest are different kinds of CCS projects Longannet was a proposed coal-fired electricity project whereas Quest is a hydrogen production CCS project. According to the IEA's CCS roadmap, Quest thus falls into the category of 'first phase' industrial applications of CCS, while Longannet does not (IEA 2013: 14). First phase projects, the IEA notes, are 
considered more mature and typically have lower additional costs than projects in the power sector. Despite substantial federal and provincial funding for the Quest project, and a last minute doubling of the price for carbon reductions secured via CCS, Shell still expects there to be a substantial financial cost for implementing CCS on its hydrogen upgrading plant. Yet this project is moving forward. As we will see soon, its link to oil sands production is critical (factor 3). However, we will argue below that the straightforward 'financial gap' explanation cannot entirely account for the differing fortunes of the two projects on its own. 
Figure 2: Key political economy factors influencing the realization of the Longannet CCS demonstration project (UK)

2. Government
policy
objectives,
frameworks
and measures
Relatively strong
framework for climate
alin.........n

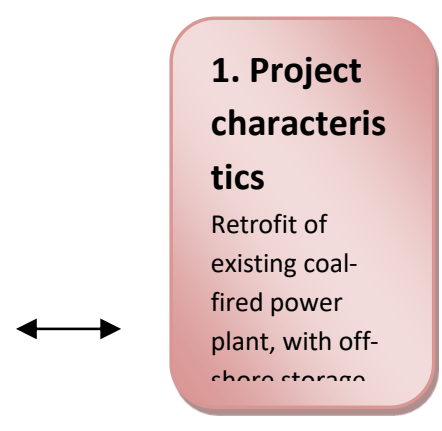

\section{Economic} factors

Major electricity firms

with competing low

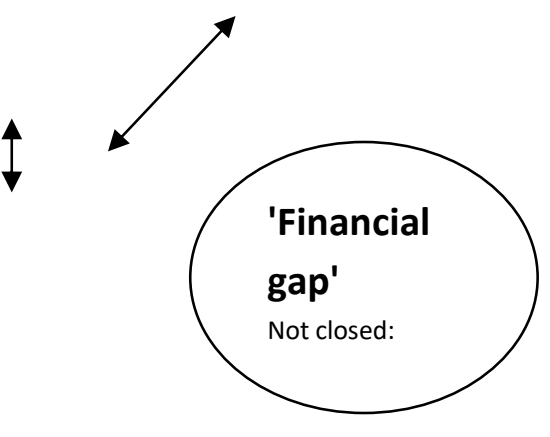

5. Public and political opposition or receotivitv to

\section{Political- institutional factors}

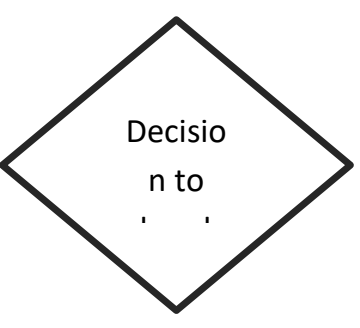

6. International dimensions

Particularly important factors in this case

Less central factors in this case

$\leftrightarrow \quad$ Strong interactions among factors 
Figure 3: Key political economy factors influencing realization of the Shell Quest CCS demonstration project (Canada)
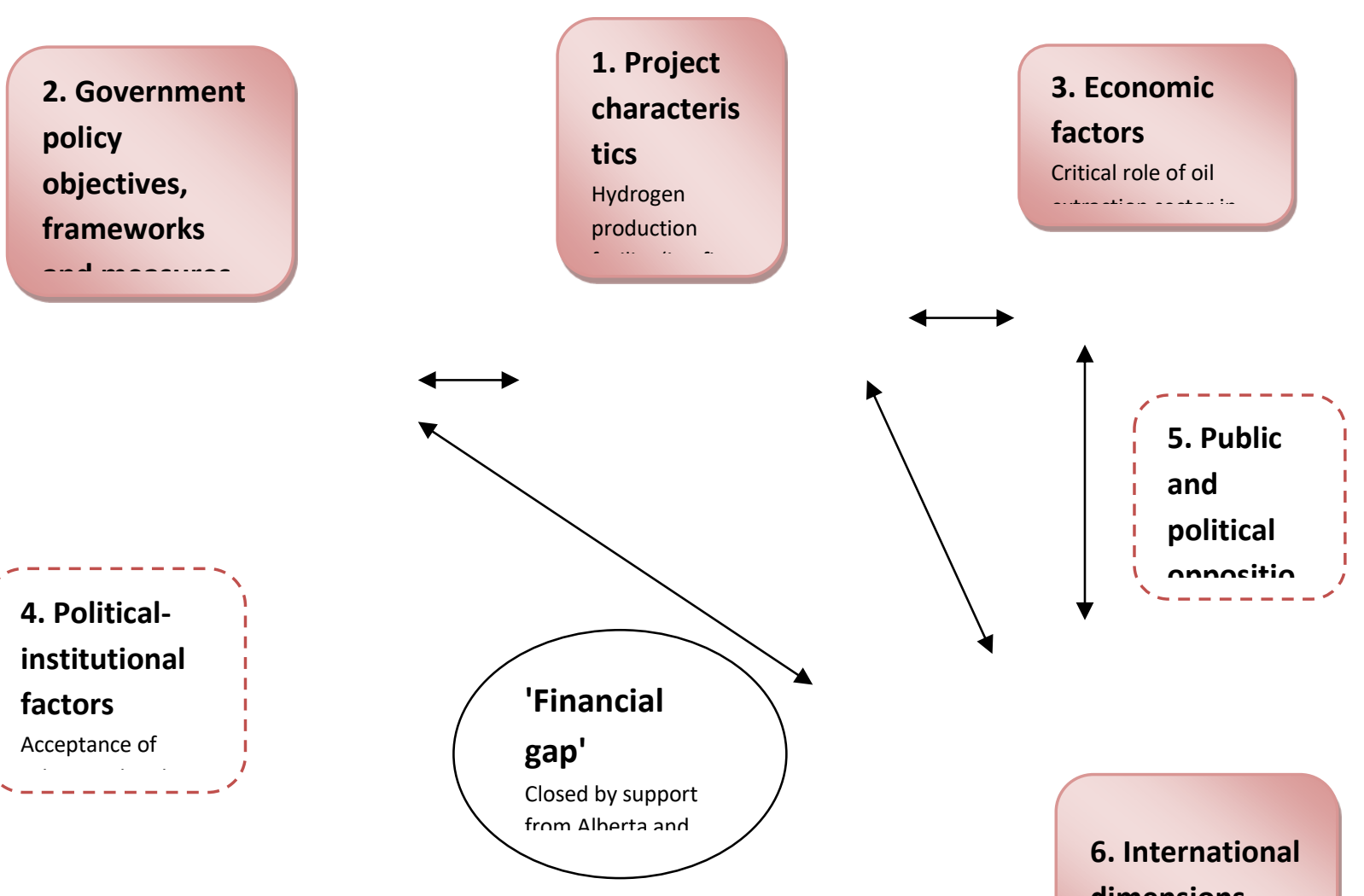

\section{Political- institutional factors Acceptance of}

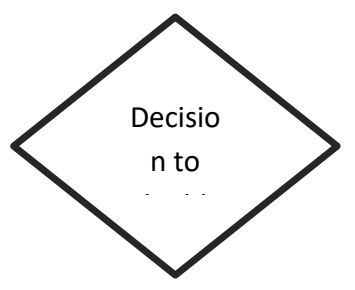

6. International dimensions Concern over internatinnal market

Particularly important factors in this case

Less central factors in this case

$\leftrightarrow \quad$ Strong interactions among factors 
With respect to government policy objectives, frameworks and measures (factor 2), both the UK and Alberta had taken steps - beginning around 2007 - toward defining a carbon reduction target, specifying the important role that CCS would play in meeting that target, and designing and implementing CCS-specific policies that would help facilitate the development of the technology. The manner in which the jurisdictions proceeded to support CCS differed, however: the UK adopted a 'competitive bidding' approach, initially restricted only to post-combustion projects in the coal power sector, while Alberta created an open technology fund not restricted to any particular type of CCS project. The impetus behind the UK's approach was a long-standing policy preference for competition (factor 4) (Kern, Kuzemko et al. 2014), driven in part by concerns about 'overpaying'. In Alberta, the aim was to promote the development of CCS through a slightly closer partnership between government and industry without restricting the type or application of the technology chosen. These different policy choices (factor 2) were thus partly influenced by institutional path dependency (in the form of policy legacies, factor 4) in both countries and the result was a more flexible policy in the Canadian case, and the consequent proposal of several CCS projects in a variety of different industries (incl. the hydrogen upgrading plant) whereas the UK government focussed narrowly on coal-fired power generation and a competition process.

Other political-institutional factors (factor 4) also played a role in shaping the different outcomes of the two planned projects. In the UK, the main government actors responsible for decisions about CCS are the Department for Energy and Climate Change (DECC), which is tasked with meeting the long-term emissions targets, and HM Treasury (the UK finance ministry), which has to approve funding for the demonstration plant, and in times of economic austerity and public sector cuts (factor 4) was hesitant to provide funding at the required scale. The Treasury also has responsibility for economic instruments affecting the energy industry. The relationship between these two Departments during the Longannet negotiations was a difficult one. The National Audit Office criticised DECC because it only "established finance for the capital costs of the project three years after its predecessor launched the competition and did not reach agreement with the Treasury on the funding for operating costs" (NAO 2012: 9). A DECC civil servant admitted that relations between the two departments were 'quite strained' during the process (Moores 2012). This made negotiations between government and CCS project consortia particularly difficult. 
Canada, on the other hand, is a federal state with a very different governance structure for energy and climate change matters, especially as they pertain to CCS (factor 4). At the federal level, Natural Resources Canada (NRCAN) is the principal department involved, administering the clean energy technology fund that has subsidized several CCS projects (including Shell Quest) as well as directly conducting research and development on CCS technologies at its CanmetENERGY research centres in Ottawa and Alberta. The natural resources portfolio is of central importance to the current Conservative government, which is strongly committed to rapid development of the resource

In terms of economic factors (factor 3), there are some economic development interests being served in the UK's moves to support economy - including hydro carbon extraction - across Canada. They see CCS as a critical technology going forward, and while many climate programs associated with the previous Liberal government have been wound down, funding for CCS has increased. Such support has been critical in enabling CCS projects to move forward.

Despite the long history of tension between the Canadian federal government and the government of Alberta over the management of energy resources (Canada's decentralized constitution places resource ownership in provincial hands), on the issue of supporting CCS and aggressively expanding oil sands production their policies have been essentially aligned. In Alberta it is the Department for Environment and Sustainable Resource Development that administers the province's climate change strategy and policies (as noted above, the strategy relies heavily on CCS to meet its targets by 2050), but importantly it is the Minister of Energy who administers the CCS fund set up in 2008 (factor 4). This joined-up push for CCS both by the federal and Albertan government is in contrast with the situation in the UK as described above which contributes to the explanation of the different faiths of the two demonstration projects. CCS. The electricity market in the UK is dominated by six large utilities which wield significant influence over energy policy decisions. These players are seen as very important in fulfilling the government's climate change ambitions. CCS promises to allow the electricity sector to adapt to the UK's carbon reduction objectives without significantly changing status quo business practices. For utilities with large existing coal fired power stations like Scottish Power

\footnotetext{
"a key reason to participate in the Government competition has been to secure the future of the almost 40-year-old Longannet power plant. With the recent flue gas desulphurization technology upgrades, the plant may continue to operate for a few decades if it can comply with future $\mathrm{CO}_{2}$ emissions regulations" (Markusson, Ishii et al. 2011: 297).
} 
Yet it is also important to note that during the competition process ScottishPower was taken over by the Spanish energy company Iberdrola, which had much less interest in the project due to the difficult economic situation in Spain but also the lack of applicability of CCS to its domestic and other international markets (Moores 2012) (factor 1). Other utilities with sunk investments in nuclear plants and less involvement in coal fired generation are even less interested in CCS, and more generally the electricity sector has a range of options for decarbonisation (e.g. new renewables as well as nuclear power) and therefore not all utilities see CCS as the way forward. One of the big areas of investment and resource potential has been offshore wind in which the UK is the world leader in terms of installed capacity (around 2.7GW at the end of 2012) (Kern, Smith et al. 2014).

Coal mining is no longer a significant economic activity in the UK (Turnheim and Geels 2012), so there is no strong coal lobby involved in UK CCS policy decisions (factor 3). The existing oil and gas companies as well as National Grid potentially have an interest in preserving their business model in the short and medium term focussing on additional production capacity in the North Sea and using the existing pipeline network for the transport of $\mathrm{CO}_{2}$, but on the other hand declining domestic reserves make this incentive to adopt CCS in the long-term less important. Interview evidence pointed to the fact that both Shell and National Grid were much less committed and active in the Longannet process compared to ScottishPower (Moores 2012).

In contrast, while CCS could be used to enable continued use of fossil fuel resources in power generation in the UK, the overall value of decarbonized fossil fuel electricity through CCS pales in comparison to the value of the resources that could be 'unlocked' in Canada through the use of the technology (factor 3 ). We consider CCS to 'unlock' some fossil fuel resources, not because the technology is integral to their production, but because in an increasingly carbon conscious world any decrease in the overall carbon content of these fuels makes them that much more marketable on international markets (factors 3 and 6). In other words, unconventional fossil fuel resources - in particular the oilsands - are one of the largest 'emissions-intensive, trade-exposed' industries. Of the $21 \%$ of Albertan GDP that comes from energy exports, $95 \%$ of that is from fossil fuel exports to the US alone. That means that almost $1 / 5$ th of Alberta's GDP is directly exposed to actions taken to address climate change in the US, which in terms of our framework means that there is a strong interaction between international dimensions (e.g. California's low carbon fuel standard, EU pressure in the same direction) and domestic economic and political factors. 
It is therefore not surprising that policies such as California's low carbon fuel standard, as well as anticipated similar policies in Europe (factor 6 ), would be a key inducement to province officials and industry to support projects such as Quest that can reduce the carbon intensity of oil sands operations. Fuel standard regulations require the life-cycle emissions of fuels to meet a declining target based on expectations about the best available technology or fuel at a given time. For the Californian standard, the 2011 maximum was supposed to be $\sim 96$ grams of $\mathrm{CO}_{2}$ per liter. As Shell itself mentions in its informational pamphlet on the oil sands, recent studies suggests bitumen derived fuels are around 5$15 \%$ more carbon intensive than an average barrel of US crude on a 'wells-to-wheel' basis - almost exactly what Shell submitted for its environmental assessment of Quest (Stantec 2010:s 5.7.1.7). In other words, with the addition of the Quest CCS facility, the unconventional crude oil produced in the Athabasca Oilsands Project is expected to have a carbon content of almost exactly the target value set in California's standard.

In terms of public and political opposition to CCS (factor 5), neither project stirred significant opposition. The proposed Longannet project has been "supported by an array of stakeholders and has had minimal public opposition" (Markusson, Ishii et al. 2011: 297). In Alberta, where there is general acceptance of the centrality of hydrocarbon extraction to the provinces economic future and communities are used to hosting oil and gas operations, there was virtually no opposition. And yet, no doubt influenced by negative experience in other jurisdictions, Shell undertook extensive stakeholder consultations and invested considerable resources in community engagement throughout the Quest project.

\section{Conclusion}

Our analysis suggests that the interplay between different sets of factors, especially project types and policy orientations (in both cases) with political-institutional elements (in the UK case) and economic factors and international elements (in the Canadian case) explain the differing outcomes. One somewhat surprising feature of these cases is that the UK has been known as a climate leader, with a relatively developed policy framework, while Canada has consistently failed to meet aspirational emissions reductions targets and has yet to introduce a national carbon pricing regime, but it is the Canadian project that went ahead. Here the lure of continuing to exploit massive fossil reserves, and the potential threat to market access, provided a powerful incentive for public and private actors to ensure 
Shell Quest went ahead. These findings support our earlier contention that the relative significance of the major factors illustrated in Figure 1 and Table 1, and the specific items that are salient under each of the general headings, will vary in different CCS demonstration projects and cannot be determined a priori.

Yet, we believe the two case studies illustrate the value of the framework in guiding analytical attention and highlighting key sets of issues. Indeed this political economy derived framework could quite usefully be applied to understand outcomes at other CCS demonstration projects. For example, Boundary Dam, the first commercial scale pulverised coal plant retrofitted with CCS has commenced operations in Saskatchewan in October 2014. With this project there is a double fossil dividend (the plant runs on locally sourced high sulfur coal for which there is no alternative market (factor 3), and the captured $\mathrm{CO}_{2}$ is being sold for enhanced oil recovery at the Weyburn-Midale field, providing the operator with enhanced income and the province with additional revenues through oil royalties (factors 1 and 3), and the project proponent SaskPower is a provincially-owned utility (factor 1). Or, the Barendrecht project in the Netherlands where public opposition played a critical role in the project cancellation (factor 5), but project characteristics (storage proposed under a residential neighborhood, factor 1 ) and policy frameworks were also part of the story (Brunsting, Best-Waldhober et al. 2011). This suggests an avenue for usefully extending this research. By employing this analytical framework to build up a wider bank of case studies, it may then be possible to determine whether some patterns of interaction among the key political-economy factors influencing the fate of proposed CCS demonstration projects are particularly common, and to explore the causes of this regularity. In this way our understanding of political economic interactions at different scales around CCS demonstration projects could be further extended and our analytical framework further refined.

The aim of the paper was to elucidate the difficulty of technological demonstration, despite some levels of support from both industry and government, in a way that goes beyond the conventional explanation that simply points to the 'financial gap' for CCS. Rather, we argued the challenge of CCS demonstration arises out of the complex interplay of political and economic factors, at multiple levels of governance, which influence state and industry decision-making surrounding energy and climate change policy and mitigation options. 


\section{Acknowledgements}

Florian Kern and Jim Watson gratefully acknowledge funding from NERC for the UKERC project 'Carbon Capture and Storage - Realising the Potential?' (award numbers NE/ H013555/1, NE/H013326/1 and $\mathrm{NE} / \mathrm{H} 013474 / 1$ ) as well as funding from the ESRC for the project 'The politics of low carbon innovation' (RES-062-23-2326). James Meadowcroft acknowledges the continuing support of the Canada Research Chairs Program and Carbon Management Canada. We would also like to thank James Moores for research assistance for the UK case study. 


\section{References}

Abadie, L. M. and J. M. Chamorro (2008). "European CO2 prices and carbon capture investments." Energy Economics 30(6): 2992-3015.

Alberta Carbon Capture and Storage Development Council. Accelerating Carbon Capture and Storage Implementation in Alberta. Edmonton, AB, March 4, 2009.

K. Backstrand, J. Meadowcroft and M. Oppenheimer (2011). "The Politics and Policy of Carbon Capture and Storage: Framing an Emergent Technology", Global Environmental Change 21(2): 275-281.

Balat, M., H. Balat, et al. (2009). "Applications of Carbon Dioxide Capture and Storage Technologies in Reducing Emissions from Fossil-fired Power Plants." Energy Sources Part a-Recovery Utilization and Environmental Effects 31(16): 1473-1486.

Bergerson, J. A. and L. B. Lave (2007). "Baseload coal investment decisions under uncertain carbon legislation." Environmental Science \& Technology 41(10): 3431-3436.

Bistline, J. E. and V. Rai (2010). "The role of carbon capture technologies in greenhouse gas emissionsreduction models: A parametric study for the US power sector." Energy Policy 38(2): 1177-1191.

Brunsting, S., M. d. Best-Waldhober, et al. (2011). "Stakeholder participation practices and onshore CCS: Lessons from the dutch CCS case barendrecht." Energy Procedia 4(0): 6376-6383.

Chang, H.-J. (2002). "Breaking the mould: an institutionalist political economy alternative to the neoliberal theory of the market and the state." Cambridge Journal of Economics 26(5): 539-559.

de Coninck, H., J. C. Stephens, et al. (2009). "Global learning on carbon capture and storage: A call for strong international cooperation on CCS demonstration." Energy Policy 37(6): 2161-2165.

de Coninck, H., T. Flach, et al. (2009). "The acceptability of CO2 capture and storage (CCS) in Europe: An assessment of the key determining factors: Part 1. Scientific, technical and economic dimensions." International Journal of Greenhouse Gas Control 3(3): 333-343.

DECC (2013). Preferred bidders announced in UK's f1bn CCS Competition, Press Release, 20.03.2013: https://www.gov.uk/government/news/preferred-bidders-announced-in-uk-s-1bn-ccs-competition.

DTI (2003). Energy White Paper: Our energy future - creating a low carbon economy. DTI: 142.

DTI (2007). Meeting the Energy Challenge. A White Paper on Energy: 343p.

Eberlein, B. and G. B. Doern, Eds. (2009). Governing the Energy Challenge. Canada and Germany in a Multi-Level Regional and Global Context. Toronto, Buffalo, London, University of Toronto Press.

Eom, J., J. Edmonds, et al. (in press). "The impact of near-term climate policy choices on technology and emission transition pathways." Technological Forecasting and Social Change (corrected proof).

Foxon, T. J., G. P. Hammond, et al. (2010). "Developing transition pathways for a low carbon electricity system in the UK." Technological Forecasting and Social Change 77(8): 1203-1213. 
Frieden, J. and L. Martin. "International Political Economy: Global and Domestic Interactions". Political Science: The State of the Discipline. Ed. Ira Katznelson \& Helen V Milner. New York: W.W. Norton, 2003.

Gallagher, K. S., J. P. Holdren, et al. (2006). "Energy-Technology Innovation." Annual Review of Environmental Resources 31: 193-237.

Gamble, A., A. Payne, et al. (1996). "Editorial: New political economy." New Political Economy 1(1): 5-11.

Geels, F. W. (2004). "From sectoral systems of innovation to socio-technical systems: Insights about dynamics and change from sociology and institutional theory." Research Policy 33(6-7): 897-920.

Geels, F. W. (2002). Technological transitions as evolutionary reconfiguration processes: a multi-level perspective and a case-study. Research policy, 31(8), 1257-1274.

George, A. L. and A. Bennett (2005). Case Studies and Theory Development in the Social Sciences. Cambridge, London, MIT Press.

Global CCS Institute (2013). The Global Status of CCS. Update January 2013. Canberra, Global Carbon Capture and Storage Institute Ltd.

Groenenberg, H. and H. de Coninck (2008). "Effective EU and Member State policies for stimulating CCS." International Journal of Greenhouse Gas Control 2(4): 653-664.

Hay, C. (2004). "Ideas, interests and institutions in the comparative political economy of great transformations." Review of International Political Economy 11(1): 204-226.

Hayward, S. (1998). "Towards a political economy of biotechnology development: A sectoral analysis of Europe." New Political Economy 3(1): 79-101.

HM Government (2009). The UK Low Carbon Transition Plan. National Strategy for Climate and Energy. London, Department for Energy and Climate Change: 220p.

HM Government (2010). Clean coal: an industrial strategy for the development of carbon capture and storage across the UK. Department of Energy and Climate Change, http://www.decc.gov.uk/en/content/cms/what we do/uk supply/energy mix/ccs/occs/occs.a spx.

IEA (2010). Energy Technology Perspectives 2010. Scenarios and Strategies to 2050. Paris, International Energy Agency/OECD: 710p.

IEA (2010a). Energy Technology Perspectives 2010. Scenarios and Strategies to 2050. Paris, International Energy Agency/OECD: 710p.

IEA (2010b). Energy Policy of IEA countries: Canada 2009 Review. Paris, International Energy Agency.

IEA (2013) Technology Roadmap Carbon Capture and Storage. Paris, International Energy Agency.IPCC (2014) Assessing Transformation Pathways. In: Climate Change 2014: Mitigation of Climate Change. Contribution of Working Group III to the Fifth Assessment Report of the Intergovernmental Panel on Climate Change. 
IPCC (2005). Special Report: Carbon Dioxide Capture and Storage, IPCC: http://www.ipcc.ch/pdf/specialreports/srccs/srccs wholereport.pdf.

Iyer, G., N. Hultman, et al. (in press). "Diffusion of low-carbon technologies and the feasibility of longterm climate targets." Technological Forecasting and Social Change (corrected proof).

Kern, F. (2011). "Ideas, institutions, and interests: explaining policy divergence in fostering 'system innovations' towards sustainability." Environment and Planning C: Government and Policy 29(6): 1116-1134.

Kern, F., A. Smith, et al. (2014). "From laggard to leader: Explaining offshore wind developments in the UK." Energy Policy 69(0): 635-646.

Kern, F., C. Kuzemko, et al. (2014). "Measuring and explaining policy paradigm change: the case of UK energy policy." Policy \& Politics 42(4): 513-530.

Kuzemko, C. (2013) The Energy Security-Climate Nexus: Institutional Change in the UK and Beyond. Basingstoke and New York: Palgrave Macmillan.

Leach, A. (2012) 'Alberta's specified gas emitters regulation', Canadian Tax Journal 60:881-98.

Macdonald, D. (2009), "Explaining the Failure of Canadian Climate Change Policy", in Turning Down the Heat: The Politics of Climate Policy in Affluent Countries, edited by Hugh Compston and Ian Bailey, Palgrave Macmillan.

Markusson, N., A. Ishii, et al. (2011). "The social and political complexities of learning in carbon capture and storage demonstration projects." Global Environmental Change 21(2): 293-302.

Markusson, N., F. Kern, et al. (2012). "A socio-technical framework for assessing the viability of carbon capture and storage technology." Technological Forecasting and Social Change 79(5): 903-918.

Mazzucato, M. (2014). The Entrepreneurial State: Debunking Public vs. Private Sector Myths. Revised edition. Anthem Frontiers of Global Political Economy. London; New York: Anthem Press.

Meadowcroft, J. (2005). "Environmental political economy, technological transitions and the state." New Political Economy 10(4): 479-498.

Meadowcroft, J. and O. Langhelle (2009). The politics and policy of carbon capture and storage. Caching the Carbon. The Politics and Policy of Carbon Capture and Storage. J. Meadowcroft and 0. Langhelle. Cheltenham and Northampton, Edward Elgar: 1-21.

Mikler, J. and N. E. Harrison (2011). "Varieties of Capitalism and Technological Innovation for Climate Change Mitigation." New Political Economy: 1-30.

Moores, J. (2012). "Technology Demonstration of Carbon Capture and Storage in the UK: A Political Economy Perspective", unpublished SPRU MSc dissertation, Brighton 2012.

Nykvist, B. and L. Whitmarsh (2008). "A multi-level analysis of sustainable mobility transitions: Niche development in the UK and Sweden." Technological Forecasting and Social Change 75(9): 13731387.

Oatley, T. (2015). International Political Economy, Pearson, Cambridge. 
Otto, V. M. and J. Reilly (2008). "Directed technical change and the adoption of CO2 abatement technology: The case of $\mathrm{CO} 2$ capture and storage." Energy Economics 30(6): 2879-2898.

Riahi, K., A. Grübler, et al. (2007). "Scenarios of long-term socio-economic and environmental development under climate stabilization." Technological Forecasting and Social Change 74(7): 887-935.

Rodrik, D. "Industrial Policy for the Twenty-First Century." Cambridge, MA: UNIDO, 2004.

Rodrik, D. "Green Industrial Policy." Oxford Review of Economic Policy 30, no. 3 (September 1, 2014): 469-91. doi:10.1093/oxrep/gru025.

Rosental, C., 2005. Making science and technology results public - a sociology of demos. In: Latour, B., Weibel, P. (Eds.), Making Things Public: Atmospheres of Democracy. MIT Press, Cambridge, MA, USA.

Rubin, E., C. Chen, et al. (2007). "Cost and performance of fossil fuel power plants with CO2 capture and storage." Energy Policy 35(9): 4444-4454.

Schwarzer, J. "Industrial Policy for a Green Economy." Winnipeg: The International Institute for Sustainable Development, 2013. https://www.iisd.org/sites/default/files/pdf/2012/energy_intensive_industries.pdf.

Scrase, I. and G. MacKerron (2009). Energy for the Future. A New Agenda. Basingstoke and New York, Palgrave Macmillan.

Scrase, I. and J. Watson (2009). CCS in the UK: Squaring Coal Use with Climate Change? Caching the Carbon. The Politics and Policy of Carbon Capture and Storage. J. Meadowcroft and O. Langhelle. Cheltenham and Northampton, Edward Elgar: 158-185.

Scrase, J. I. and J. Watson (2009). "Strategies for the deployment of CCS technologies in the UK: a critical review." Energy Procedia 1(1): 4535-4542.

Shackley, S., D. Reiner, et al. (2009). "The acceptability of CO2 capture and storage (CCS) in Europe: An assessment of the key determining factors: Part 2. The social acceptability of CCS and the wider impacts and repercussions of its implementation." International Journal of Greenhouse Gas Control 3(3): 344-356.

Shapin, S., 1984. Pump and circumstance: Robert Boyle's literary technology. Social Studies of Science 14 (4), 481-520.

Shell n.d. Athabasca Oil Sands Project, http://www.shell.com/home/content/aboutshell/our_strategy/major_projects_2/athabasca/ov erview/\#subtitle_4.

Stantec Consulting Inc. (2010) Volume 1: Project Description. Environmental Assessment. Quest Carbon Capture and Storage Project. Calgary, AB: Shell Canada Ltd., November 2010.

Stantec Consulting Inc. (2010) Volume 2A: Environmental Assessment Sections 1-8. Environmental Assessment. Quest Carbon Capture and Storage Project. Calgary, AB: Shell Canada Ltd., November 2010. 
Stephens, J. C. (2014), Time to stop investing in carbon capture and storage and reduce government subsidies of fossil-fuels. WIREs Clim Change, 5: 169-173. doi: 10.1002/wcc.266

Szolgayova, J., S. Fuss, et al. (2008). "Assessing the effects of CO2 price caps on electricity investments-A real options analysis." Energy Policy 36(10): 3974-3981.

Torvanger, A. and J. Meadowcroft (2011). "The political economy of technology support: Making decisions about carbon capture and storage and low carbon energy technologies." Global Environmental Change 21(2): 303-312.

Turnheim, B. and F. Geels 2012 Regime destabilisation as the flipside of energy transitions: Lessons from the history of the British coal industry (1913-1997), Energy Policy, Volume 50, November 2012, Pages 35-49.

Unruh, G. C. (2000). "Understanding carbon lock-in." Energy Policy 28(12): 817-830.

van Alphen, K., M. P. Hekkert, et al. (2010). "Accelerating the deployment of carbon capture and storage technologies by strengthening the innovation system." International Journal of Greenhouse Gas Control 4(2): 396-409.

van Alphen, K., Q. V. T. Voorst, et al. (2007). "Societal acceptance of carbon capture and storage technologies." Energy Policy 35(8): 4368-4380.

van der Zwaan, B. and R. Gerlagh (2009). "Economics of geological CO2 storage and leakage." Climatic Change 93(3-4): 285-309.

Vass, S. (2013). "Carbon tax cost killed off ScottishPower's Longannet CCS plan". Sunday Herald, 20.01.2013.

Verbong, G. and D. Loorbach (2012). Governing the Energy Transition. Reality, Illusion or Necessity? New York, London, Routledge.

Vergragt, P. (2012). Carbon Capture and Storage. Sustainable Solution or Reinforced Carbon Lock-In. Governing the Energy Transition. Reality, Illusion or Necessity. G. Verbong and D. Loorbach. New York and Abingdon, Routledge.

von Stechow, C., J. Watson, et al. (2011). "Policy incentives for carbon capture and storage technologies in Europe: A qualitative multi-criteria analysis." Global Environmental Change 21(2): 346-357.

Watson, J., F. Kern, et al. (2014). "Resolving or managing uncertainties for carbon capture and storage: Lessons from historical analogues." Technological Forecasting and Social Change 81(0): 192-204.

Wynn, G. (2012). "Shell CO2 Capture Bets on Emissions Targets." Financial Post, September 7, 2012.

http://business.financialpost.com/2012/09/07/shell-co2-capture-bets-on-emissions-targets/.

Florian Kern is a Senior Lecturer at SPRU-Science Policy Research Unit at the University of Sussex and CoDirector of the Sussex Energy Group. He has more than nine years of experience in research, consulting 
and teaching in the area of energy, climate and innovation policy. His research combines ideas from innovation studies and policy studies/political science to investigate the politics and governance of innovation for low carbon energy systems and sustainability transitions. His research has been published in journals such as Technological Forecasting \& Social Change, Energy Policy, Environment and Planning C, Policy Sciences and Policy \& Politics.

James Gaede is a recent Ph.D graduate from the Political Science program at Carleton University in Ottawa, where his field specializations where international relations and comparative politics. He wrote his thesis on the politics of 'observing' the future for sustainable energy, looking in particular at controversy surrounding the International Energy Agency's World Energy Outlook, between 1998 and 2008. His primary research interests are in the politics of information, decision-making and judgement in the governance of sustainable energy transitions.

James Meadowcroft holds a Canada Research Chair in Governance for Sustainable Development and is a Professor in the School of Public Policy and Administration, and in the Department of Political Science, at Carleton University in Ottawa. His research focuses on reforms to structures and processes of governance to promote transitions towards sustainability. He has written widely on sustainable development, and on energy and environmental politics and policy, including recent work on carbon capture and storage, smart grids, the development of Ontario's electricity system, the potential for solar photovoltaics in Canada, the politics of socio-technical transitions, and negative carbon emissions.

Jim Watson is Research Director of the UK Energy Research Centre and Professor of Energy Policy at the University of Sussex. He was Director of the Sussex Energy Group at Sussex from Dec 2008 to Jan 2013. He has 20 years' research experience on climate change, energy and innovation policy. He frequently advises UK government departments and other organisations, and has been a Specialist Adviser to two House of Commons Select Committees. Jim is a council member of the British Institute for Energy Economics, and was its chair in 2011. He is also a member of DECC and Defra's social science expert panel.

\footnotetext{
${ }^{1}$ This policy instrument has been included as part of the electricity market reform in the UK. Contracts for difference provide long term contracts for generators which provide extra revenue on top of the normal electricity price to incentivise investment in low carbon generation options including CCS, nuclear power or offshore wind.

${ }^{2}$ Curiously, this carbon price is now higher than the carbon price set by the EU Emissions Trading Scheme which has dropped to under $€ 5$ recently which is why the UK government has adopted a domestic carbon floor price to incentivise investment in low carbon generation.

${ }^{3}$ If Quest manages to store its projected $\sim 1 \mathrm{~m}$ tonnes annually, this double-crediting could produce an additional \$30m annual revenue stream. See Wynn (2012)
} 